\title{
The operating mode Optimization of Chinese electric car charging piles \\ Yurong Zeng ${ }^{1}$, Mengting Long ${ }^{2}$
}

1. School of Economic and Management, North China Electric Power University, Beijing, China, 102206; Email: hdddqccdz@163.com.

2. School of Economic and Management, North China Electric Power University, Beijing, China, 102206; Email: 13264421172@163.com.

Keywords: Charging piles Operating mode Optimization Analysis Suggestions

\begin{abstract}
Charging pile, an important supporting infrastructure, is necessary for the development of electric cars. In this paper, combined with Chinese actual situation, we propose that currently car manufacturers should implement the alliance charging pile model between car manufacturers and power grid enterprises based on the analysis of the pros and cons of the three modes such as the charge pile operating modes led by government, power companies and Automobile manufacturers. Finally, we suggest some methods for long-term development of electric vehicle charging piles in China to provide theoretical basis to help the construction and improvement of charging piles.

Electric cars have broad prospects for future development as a means of transport. Electric vehicle charging piles provide energy supply for electric cars to run normally, which is an important and necessary supporting infrastructure for the development of electric cars.
\end{abstract}

\section{Introduction}

According to the data of the Chinese Ministry, the production of new energy automobile cars reaches 24500 in August, an increase of nearly 4 times. Between January and August 2015, the cumulative production of new energy vehicles is 123,500, an increase of 3 times. Despite the development of new energy vehicles still faces many obstacles especially the charging problem, relevant state departments and enterprises try their best to improve charge pile market, hoping to wipe out this "last kilometer barrier." At the same time, on February 24, 2016, the State Council, Li Keqiang chaired a State Council executive meeting to continuously release five key measures promoting new energy automotive industry. Not only do they focus on charging infrastructure, but also they urge the improvement of relevant financial subsidies and provide other support policies to encourage social capital into the charging facility construction and operation. This marks that the new energy vehicle charging pile will gradually be on the standardized and consistent road. With the continuous expansion of new energy vehicle market, charging market will also get more and more opportunities.

However, the Chinese market is still in infancy process, many models are still at an experimental stage and its profit model is not decided finally. As the saying lying in the commercial war goes "In blue ocean, the competition is out of the question, because the rules of the game have not yet been developed", competition rules should be established appropriately. It is certain how we can take the lead in the blue ocean in the new national standard era will undoubtedly become the trigger point. In this case, it is vital for the domestic electric car manufacturers to absorb the mature business model of abroad electric car charging pile. 


\section{Overseas development of charge pile construction}

2.1 United States: Private robust charging network that gave birth to the world's largest market

America's current leading position in the new energy automotive industry can be concluded from the following main factors:

- Construct charging network facility based on the starting point to build a smart grid.

- Develop strong policies to encourage the construction of charging facilities.

- Construct unified standard to greatly enrich private AC charging and promoting car models.

- Develop specialized charging operations and service enterprises to improve experience of the charging users.

2.2 Japan: Policy Support + technology leader, The charge pile construction walks in the forefront of the global.

On May 2014, Toyota, four car manufacturers such as Nissan, Honda and Mitsubishi Motors combined with the Bank of Japan jointly set up a new company called "Japanese charging service (NCS)", which is aimed at the charging pile installation, operation, and 8-year free warranty. In the construction of NCS charging service network, operational offices, hotels, convenience stores, motorway service areas, car parks, railway stations and other businesses provide charging facilities and the application to use. The NCS bears the construction cost of charging facilities and an universal charge card for four car manufacturers users. Four car manufacturers purchase the right to use charging facilities from NCS and charge user fees by way of membership. By the beginning of 2015, the number of charging pile country has been more than 40,000 (including home charging pile), which exceeds the traditional gas station number of 34000. CHAdeMO (Japan Electric Vehicle Fast Charger Association) standard fast charge pile is the representative of Japanese DC fast charge pile. Currently 38 countries and over 341 organizations have joined CHAdeMO Association, including energy companies, automobile companies, enterprises and other facilities charge. The number of CHAdeMO fast charging pile in Japanese and the world reach for respectively 3087 and 5735.

2.3 France: construction of charging facilities driven by electric car rental project.

Autolib project, the electric car-sharing rental program, is currently the world's largest scale and its impact is huge. It was officially launched in late 2011. Currently in Paris urban areas, it will be able to find a charging point every 250 meters on average. After Joining Autolib project, not only can members book mobile electric cars via online, you can also reserve a space in the destination and choose the nearest charging stations for consumers based on the remaining charge. Autolib project spreads in public charging stations throughout Paris and several residential areas in other major cities. As long as the car is parked in a private parking spot, the user does not have to bear the parking fees. Autolib rental points charging facility is also open to private pure electric vehicles and the annual cost per vehicle is 180 euros. Paris Autolib electric car rental project operator of Bolloré Group announced plans to invest 150 million euros in four years building 16000 charging stations (rental points) in the country and provide $7 \mathrm{~kW}$ single-phase and $22 \mathrm{~kW}$ three-phase charging to form the charging network at the interval of less than $40 \mathrm{~km}$ in the country.

\section{Operating mode analysis of Chinese electric car charging pile}

There are three international mainstream charging pile operating mode currently, such as the government led the charge pile operating mode, power companies led the charge pile operating mode, auto manufacturers led the charge pile operating mode. 
3.1 Government led the charge pile operating mode. It is an operational way that government, as the investor of electric car charging pile, organizes car manufacturers, electricity suppliers and equipment suppliers to participate in the construction of the operational charging pile. This mode is suitable for the early development of electric vehicles and small-scale commercial operation phase. The need for government to do is encourage and support enterprises engaged in charge pile construction. Government-funded construction and operation of charging pile can promote the development of electric vehicles and the implementation of commercial operation though losses can be generated by the financial burden. However, with the increase of the number of charging pile and the investment demand, it is difficult for government financial office to support due to the lack of market competition, leaving the charging pile projects inefficient.

3.2 Power companies led the charge pile operating mode. It means that the power grid enterprises, as investors of electric vehicle charging pile, are responsible for electric vehicle charging pile construction and their operation with full commercialization. This mode is suitable for the market of the open commercialization of electric vehicles, the relatively stable service charge demand and the smooth of investment channels. It is optimistic for power grid enterprises to build charging pile about the earnings outlook charging pile, charging poles with power grid construction resources, network transmission advantages and technological advantages of the standard. However, the lack of terminal sales network and operational experience charge pile cannot be ignored.

3.3 Automobile manufacturers led the charge pile operating mode. It indicates that car manufacturers need to make investments in construction to promote the popularization of electric vehicles. This mode is suitable for the development stage where the scale of commercial operation of electric vehicles is large, commercial condition is ripe and the investment channels are smooth. The investment in charging pile of automobile manufacturers is regarded as part of the electric vehicle market after the service that the product and services value chain are integrated. However, when the charging pile massively increases, the power and technology provided may not meet the actual demand.

According to the analysis on advantages and disadvantages of the three operating modes above, China will be better to adopt an ideal choice of alliance model called "automobile manufacturers + grid enterprises", which means automobile manufacturers and power grid enterprises get together to construct the operation of charge pile, rather than a particular model alone. Electricity grid companies have conditions of providing electric power, while car manufacturers own network of sales terminals and operating experience. The cooperation between the two parts can reach a win-win situation. It is difficult for car manufacturers to break the technical problems of power. The charge pile construction of grid companies is also inseparable from automobile manufacturers. However, the alliance can be complement to each other, which means they can promote electric cars into unified standard and the process of the electric car market to better meet the demand of charging pile operational construction currently.

\begin{tabular}{|l|l|l|l|l|l|}
\hline & \multicolumn{2}{|l|}{ city } & highway \\
\hline project & $\begin{array}{l}\text { charging } \\
\text { stations } \\
\text { for } \\
\text { passenger } \\
\text { vehicle }\end{array}$ & $\begin{array}{l}\text { charging } \\
\text { statuins } \\
\text { for bus }\end{array}$ & $\begin{array}{l}\text { DC } \\
\text { charge } \\
\text { spots }\end{array}$ & $\begin{array}{l}\text { AC } \\
\text { charge } \\
\text { spots }\end{array}$ & $\begin{array}{l}\text { fast-charging } \\
\text { station }\end{array}$ \\
\hline Device Configuration & $30 \mathrm{kw}$ & $60 \mathrm{kw}$ & $30 \mathrm{kw}$ & $7 \mathrm{kw}$ & $120 \mathrm{kw}$ \\
\hline
\end{tabular}




\begin{tabular}{|l|l|l|l|l|l|l|}
\hline service vehicle type & $\begin{array}{l}\text { Electric } \\
\text { bus }\end{array}$ & $\begin{array}{l}\text { Electric } \\
\text { taxi }\end{array}$ & $\begin{array}{l}\text { Electric } \\
\text { passager } \\
\text { car }\end{array}$ & $\begin{array}{l}\text { Electric } \\
\text { passager } \\
\text { car }\end{array}$ & $\begin{array}{l}\text { Electric } \\
\text { passager car }\end{array}$ \\
\hline \multirow{2}{*}{ construction place } & $\begin{array}{l}\text { public } \\
\text { park }\end{array}$ & $\begin{array}{l}\text { bus } \\
\text { station }\end{array}$ & $\begin{array}{l}\text { public } \\
\text { park }\end{array}$ & $\begin{array}{l}\text { public } \\
\text { park }\end{array}$ & $\begin{array}{l}\text { expressway } \\
\text { service area }\end{array}$ \\
\hline area/Square meters & 2420 & 3853 & 0.5 & 0.3 & 98 \\
\hline $\begin{array}{l}\text { investment ( ten- } \\
\text { thousand-yuan }\end{array}$ & equipment & 415 & 342 & 7.2 & 0.5 & 80 \\
\cline { 2 - 7 } & construction & 102 & 110 & 0.3 & 0.12 & \\
\cline { 2 - 7 } & $\begin{array}{l}\text { distribution } \\
\text { facilities }\end{array}$ & 110 & 95 & & & 40 \\
\cline { 2 - 7 } & $\begin{array}{l}\text { Installation } \\
\text { expenses }\end{array}$ & 78 & 65 & 0.4 & 0.1 & \\
\cline { 2 - 7 } & other chatges & 42 & 36 & 0.5 & 0.06 & 120 \\
\cline { 2 - 7 } & sum & 750 & 638 & 8.4 & 0.78 & 3.4 \\
\hline \multirow{3}{*}{ benefit } & $\begin{array}{l}\text { annual return } \\
\text { /ten- } \\
\text { thousand-yuan }\end{array}$ & 101.8 & 135.8 & 1.1 & 0.3 & 35 \\
\cline { 2 - 4 } & $\begin{array}{l}\text { payback } \\
\text { period/year }\end{array}$ & 7.4 & 4.8 & 7.5 & 2.6 & \\
\hline
\end{tabular}

\section{Suggestions on the construction of electric car charging pile}

\subsection{Construction of fiscal and taxation preferential system}

The fiscal and taxation preferential system is one of the important driving forces in industrial development of charging facilities, including direct financial grants, investment and financing system and the establishment of industry funds. Chinese government should expand the range of infrastructure demonstration operating projects. The pilot cities of electric vehicle development cannot rely solely on the local government's financial input, the central government may be appropriate for local financial subsidies. At the same time, they should guide private enterprises and independent local investors to participate in the construction of a demonstration project to expand the sources of project funding and establish a reasonable investment and financing system like the standardization of government investment and financing behavior. The establishment charging facility industry fund, sources of funding can be imposed by a certain percentage of the fuel tax, high pollution fees way to raise the car.

4.2 Improvements of technical standards and test detection system

Chinese government should try their best to improve the technical standard system and actively participate in deciding international standards to attract more rights to speak. In developing the standard of charging facilities, not only should we consider international standards, but also the needs of product quality and market competition needs China's special conditions. Standards should be maintained highly systematic, integrity, focused on supporting industries, harmonization of standards to ensure the authority, consistency, uniform national standards and industry standards. The development of quality control mechanisms and strict quality detection mechanisms are supposed to protect the quality of new energy vehicles to facilitate their rapid maturation of technology, which accelerates the rapid development of the industry. 
4.3 Innovation of technology and research supporting system

Multi-market participations in the development of key technologies need to be promoted. In the early stages of industry development, technology research and development of electric vehicles need to be guided according to the establishment of the study group of experts, charging facilities and industrial technology roadmap. We should put more research efforts and investment in charging facilities, such as real price-inch technology, networking technology, grid interactive technology, wireless charging and fast charging technology. We will try our best to make full use of international $R \& D$ results and guide the development of infrastructure industries. Moreover, in order to create our own system and technology, there is no denying that we should actively participate in international organizations related to industrialization to keep up with those advanced countries. Staff training is a serious shortage of professionals in Chinese electric vehicles and charging infrastructure, especially in urgent need of having creative talents, technical personnel and the overall complex designer righteousness.

\section{Reference:}

[1] Tianjiao Hu, Cuimin Zhen, Electric car infrastructure and operation in domestic and foreign countries [J]. Hebei United University (Social Science Edition), 2014 (1).

[2] Min Tang, Jiexian Xu, Yuelei Gu, Study on electric vehicle charging station construction and operation mode of East China Electric Power [J]. 2011 (02): 203-206.

[3] Shanyi Shen, Research on Shanghai electric vehicle and charging infrastructure operating mode [D]. Shanghai Jiaotong University, 2011.

[4] Yuntang He, Chinese electric car standard system [J]. Automobile and Parts, 2011, (44): 25-27.

[5] Zhen Zhang, Service system design research on electric vehicle charging products [J], Jiangnan University, 2013.

[6] Mang Lu, Xiaobing Zhou, Wei Zhang, Research on the development of electric vehicle charging facilities in domestic and foreign countries, Central Electric Power Research Institute, 2010.

[7] Bin Ren, Luning Shao, xin Jian, Innovation of diffusion theory on Chinese electric vehicle Generalized Bass model [J]. Soft Science, 2013 (04): 17-22. 